\author{
Askar Mambetaliev \\ University of Pannonia, Hungary
}

\title{
A COMPARATIVE STUDY OF THE GAP BETWEEN DE-JURE AND DE-FACTO LANGUAGE POLICIES: THE CASE OF KYRGYZSTAN AND HUNGARY
}

\begin{abstract}
Summary. The purpose of this study was to find the main factors that guide language policies and discover correlations between top-down and bottom-up ideologies in the context of Hungary and Kyrgyzstan. To accomplish this, the study created a database of relevant official documents, photos of linguistic landscapes and qualitative data. The study analyzed the documented top-down decisions from historical perspectives, and then compared them with the data collected from interviews and surveys, and from the collection of photos. The participants included both high-ranking political figures, professors, students and random citizens. Results showed that the official policies often do not comprehensively match with the people's beliefs, attitudes and desires. Findings also imply that using either document analysis, or the method of linguistic landscape, or qualitative methods alone, might not sufficiently validate the results in the absence of each other, since errors may top up from various discrepancies between top-down and bottom-up arrangements, as well as from overt and covert ideologies.
\end{abstract}

Keywords: Language policies; ideologies; beliefs; document analysis; linguistic landscape.

\section{Introduction}

Kyrgyzstan has always been looking for a model of language policy in Europe to follow, since unique and regionally minor languages need to learn lessons from each other's experiences. In this regard, Hungary is a European nation that shares delicate common features with Kyrgyzstan in historical development of language policies and sociolinguistic configurations. The core ethnic groups of both nations were nomads in Central Eurasia, lived in yurts and nurtured similar cultures. However, they have many differences today while modern Hungary is a monolingual country, Kyrgyzstan is a multilingual nation. Therefore, it is interesting to learn how and when their language policy models had diverted, and what contributed to the divergence. This study helps to understand the aspects of sustainable multilingualism and monolingualism, since it uses both differences and similarities to display contrasts and highlight details in explaining the factors that have contributed to the modern state of language policies and language ecologies. 
In the early years of the Bolshevik revolution, the communist party of the USSR declared linguistic liberalism in Kyrgyzstan. In the constitution of the Kyrgyz SSR, issued in 1929, Kyrgyz language had a superior position than Russian language (Second All Kirghiz Conference of the Kyrgyz ASSR, 1929). However, by the end of the 1930's, some covert ideologies began enforcing russification* (Ornstein, 1959, p. 2). As a result, minorities of the Soviet Union started shifting their languages onto the majority's language for education, career and economic purposes. During and after the WWII "by the will of God and Stalin, ethnic composition of Kyrgyzstan's population suddenly became quite varied" (Mambetaliev, 2018, p. 3) and this variety spoke the main language of the Union, making ethnic Kyrgyz a minority in their own land. As a result, a half of population in Kyrgyzstan was bilingual by 1999, but the bilingualism was asymmetric - only minorities spoke the language of the majority. Introduction of Russian on Hungarians since 1950s has not yielded a similar effect, since career and economic opportunities in the West have always been more attractive than those the East could offer. In contrast to Kyrgyzstan, which was a subject of the Union, Hungary was formally an independent nation-state during and after the soviet era. The notion, "one nation, one language" which was the motto of many politicians of Europe in the previous century, strengthened the role of state languages, including the Hungarian. At the same time, minority languages within the national borders had no better choice than "voluntary" assimilation. "As a consequence of this, most of the minorities living in Hungary today profess dual or multiple affiliations: their ties to the Hungarian culture and language are as strong as (or sometimes stronger than) their original nationality ties" (Paulik \& Solymosi, 2004). A study by Navracsics (2016, p. 12), confirms this, when she notes that Croatians of Hungary identify themselves strongly as Hungarians.

Prior to moving further, some terminologies and definitions need to be described, since language policy is a comparatively new field in applied linguistics. While researchers have developed widely shared definitions for other terms in the discipline, language policies (LP) and language ideology (LI) is prone to flexible meanings. Some earlier studies classify LI as a part of

\footnotetext{
* This article, however, does not label "russification" or "kyrgyzification" as "bad" or "good", since both are historical processes, though they sometimes led to deprivation of sociolinguistic groups from access to public services.
} 
LP (Spolsky, 2004, p. 15). This study uses it as "sets of beliefs (or ideas/conceptualizations) about language" (Ajsic \& McGroarty, 2015). Language ecologies (LE) are better explained when LI are discussed (Blackledge, 2008) and historical facts are considered. Linguistic landscape (LL) is another construct, which may reflect "a manifestation of hidden ideological agendas" (Shohamy, 2015, p. 13). Shohamy and Gorter (2009) pointed to the link between LL and LP (Gorter \& Cenoz, 2017, p. 237) and Shohamy (2015, p. 156) proposed to connect LL to LP. The study of LL has attracted a growing interest of scholars since the last decade, because the easiest way to study the LP of a place is to look at the signs on public sites and make some conclusions. Authorities often employ LL as a mechanism to promote favorable LP, since inscriptions and images at public places may impress and motivate people. LL can also serve to promote language shift by deliberate replacement of old language by a new. This change may often symbolize a transition from one regime to another (Shohamy, 2015, pp. 156158; Pavlenko, 2009, p. 254, 255; Gorter \& Cenoz, 2017, p. 235). Waksman and Shohamy $(2009,2010)$ consider political dimensions of public spaces (Shohamy, 2015, p. 154, 155). Gorter \& Cenoz (2017) suggest that the signs show relationships within the society and can help in explaining the processes between languages in different contexts, since "LL reflects people's needs and 'every day' practices" (Shohamy, 2015, p. 166). Communities change LL by initiating LP as a necessary part of daily needs. On the other hand, official LP often may not ideally match with LI and LL. As Spolsky (2004) pointed, "[l]ooking at the language policy of established nations, one commonly finds major disparities between the language policy laid down in the constitution and the actual practices in the society" (p. 217). Further he stated, "look at what people do and not at what they think they should do or at what someone else wants them to do" (Spolsky, 2004, p. 2018). However, "people" in this statement may represent different groups, who "do" and "think" differently. Attitudes about languages of students studying business administration, for example, may significantly differ from the attitudes of students majoring in other sciences, and the attitudes may effect on learning particular languages (Rukh, 2014). Attitudes may vary among groups of social strata - the elite may hold a different LI than lower classes (Raza, 2015, p. 107). Cultural attitudes towards language varieties often effect perceptions of particular 
languages (Bayley \& Villarreal, 2018).

Unfortunately, most of the studies in this field are more than 10 years old. In addition, few articles addressed the variables discussed above. For Kyrgyzstan, publications are mostly about chronological development of LP (Chotaeva, 2002; Mustajoki, Orusbaev, \& Protassova, 2008; Pavlenko, 2009), attitudes and language rights (Huskey, 1995; Korth, 2005; Grigorieva and Parmanasova, 2007; Orusbaev et al. 2008; Ahn \& Smagulova, 2016). In Hungary, they are about LL (Paulik \& Solymosi, 2004; Batyi, 2015), the role of English (Dorottya, 2011) and identity issues among minorities (Navracsics J., 2016). Moreover, analysis of the interaction of official documents, language ideologies (LI) and language use (LU), employing comparative approaches involving several countries is a deficit. Even the link between the only two variables - LP and LL, or LP and LU - in the context of several countries needs a fresh look.

Another problem in the study is that, using either the document analysis, or the method of $\mathrm{LL}$, or qualitative methods alone, might not sufficiently validate conclusions in the absence of each other. The errors may add up from various discrepancies between top-down and bottom-up decisions, as well as from overt and covert ideologies.

To find out the discrepancies, this study explored correlations of major domains of LP with a comparative approach in the context of Hungary and Kyrgyzstan. The mentioned domains are official decisions, top-down and bottom-up ideologies, and the languages of public signage. Hypothetically, the public signs in the capitals may represent some main LPP aspects of the country, which do not reflect, though, comprehensively, the current ecology and sociolinguistic situation in both capitals. Hence, this hypothesis leads to the research question: "What are the main factors that guide official decisions and contribute to the discrepancies between overt and covert language policies?".

\section{Methodology}

This study employed historical-structural and interpretive policy analysis (Moore \& Wiley, 2015, p. 153) of official documents published since 1929, qualitative data and exploration of the public signage in Budapest and Bishkek. 
As the first step, the researcher developed a database of relevant documents, including constitutions, laws and photos of linguistic landscape. Then he grouped them as laws on state languages, laws on advertisements and other visual information on public sites. Then he located the documents in two columns under corresponding countries in order to make an easy comparison.

Walking down from the parliament building throughout district $\mathrm{V}$ in Budapest and from $9^{\text {th }}$ micro district on the Sovetskaya Street until the parliament building in Bishkek, the researcher took arround 1000 photos in each city. While some studies prefer to use all visible signs (e.g. Gorter \& Cenoz, 2017), some others count only bi- or multilingual signs (e.g. Backhaus, 2007). In this regard, the comparative approach to the positions of minority and majority languages was in mind when taking and analyzing photos (Gorter \& Cenoz, 2017, pp. 236-237). While analyzing the signs, the researcher paid attention to such characteristics as frequency, order, translation, fonts, colors, sizes, location, primary function, etc. The government buildings in Budapest in the selected site were the Parliament, Prime Minister's Office, ministry of Human Capacities, Hungarian State Treasury National Tax and Customs Administration, Pest County Land Office, as well as street signs of private and public buildings. In Bishkek they were the Parliament, Ministry of Education and Science, Ministry of Internal Affairs, Ministry of Foreign Affairs, Ministry of Economics, Ministry of Finance, Ministry of Justice, National Statistics Committee, as well as the buildings of private and public buildings.

The researcher interviewed high-ranking political figures in the Kyrgyz Republic, responsible for LP, as well as professors, dormitory tenants and Ph.D. students of the University of Pannonia, members of the Veszprémi Evangéliumi Keresztény Gyülekezet community (Hungary), visitors of the special website (https://multil.org) and random encounters in the streets of Budapest and Bishkek. In particular, the researcher interviewed Mr. Sadyk Sherniyazov, who is the Vice-Chair of the committee for education and culture in the Kyrgyz Parliament, and Dr. Nazarkul Ishekeev, who is the Chair of the Agency for the State Language under the President of the Kyrgyz Republic. Several focus group discussions included faculty members of the Kyrgyz National University, Kyrgyz State University, Bishkek Humanitarian University and Kyrgyz-Russian Slavonic University. 


\section{Results}

The Table 1 presents the constitutions of Hungary and Kyrgyzstan. The results of the qualitative data are under the corresponding titles. All Hungarian participants supported the fundamental law of Hungary and think that Hungarian language must be the only state language in Hungary. However, the majority admit that English is also useful. The participants in Bishkek included those who support bilingualism with Russian and those who support the Kyrgyz only idea. There was also a small group of supporters of trilingualism with Russian and English.

Regarding bi- or multilingualism with English (in response to the question, "What do you think about introducing English as an additional official language in your country?") almost all answers in Hungary were similar to "the language of instruction is in Hungarian, but the number of children learning English is growing". In Bishkek, most parents were reluctant to give their children to Kyrgyz schools. Officially, only 9 out of 94 schools in Bishkek use the Kyrgyz as the MoI (Kashybaeva, 2014). Most students want to learn languages, especially English, but they graduate schools with low English proficiency.

Table 1.

\section{Main laws on the state language and attitudes towards}

the second language

\begin{tabular}{|c|c|}
\hline Hungary & Kyrgyzstan \\
\hline $\begin{array}{l}\text { I. The constitution of Hungary (1949) } \\
\text { did not mention about the language of } \\
\text { the country. The fundamental law } \\
\text { (2011, 2013, 2017) introduced the } \\
\text { following: 1) In Hungary the official } \\
\text { language shall be Hungarian. 2) } \\
\text { Hungary shall protect the Hungarian } \\
\text { language. 3) Hungary shall protect } \\
\text { Hungarian Sign Language as a part of } \\
\text { Hungarian culture. }\end{array}$ & $\begin{array}{l}\text { I. The Constitution (1929) recognized two } \\
\text { state languages in the Kirghiz ASSR: } \\
\text { Russian and Kyrgyz. The Constitution } \\
\text { (1978) inserts that Laws and Acts of the } \\
\text { Kyrgyz SSR shell be published in Kyrgyz } \\
\text { and Russian languages. The Constitution } \\
\text { (1993) introduced the term official } \\
\text { language (Russian language), which was } \\
\text { once more supported in 2010. It also } \\
\text { added, "The President must know the state } \\
\text { language. }\end{array}$ \\
\hline $\begin{array}{l}100 \% \text { support (i.e. they cannot imagine } \\
\text { that Hungary may have another state or } \\
\text { official language). } 90 \% \text { believe that }\end{array}$ & $\begin{array}{l}80 \% \text { do not support (i.e. they believe that } \\
\text { the country must have only one official } \\
\text { language and that language must be }\end{array}$ \\
\hline
\end{tabular}




\begin{tabular}{l|l}
\hline Hungary & Kyrgyzstan \\
\hline $\begin{array}{l}\text { English is useful to know and 0\% belief } \\
\text { in the usefulness of Russian language. }\end{array}$ & $\begin{array}{l}\text { Kyrgyz). 70\% believe that Russian } \\
\text { language is more needed than English. }\end{array}$ \\
$\begin{array}{l}\text { II. "The language of education shall be } \\
\text { Hungarian" (Hungarian Education } \\
\text { Office, 2011). }\end{array}$ & $\begin{array}{l}\text { II. "In all educational institutions the study } \\
\text { of Kyrgyz, Russian and one of foreign } \\
\text { languages is obligatory"(The law on } \\
\text { education, 2003). }\end{array}$ \\
$\begin{array}{l}\text { 60\% believe that introducing English as } \\
\text { the second MoI would be a positive } \\
\text { policy. 90\% monolingualism on } \\
\text { university buildings. }\end{array}$ & $\begin{array}{l}40 \% \text { believe that introducing English as } \\
\text { the second MoI would be a positive policy. } \\
100 \% \text { bilingualism on university buildings. }\end{array}$ \\
\hline
\end{tabular}

The Table 2 presents official laws about public signs and the linguistic landscape. The second row presents total numbers for all visual signs of linguistic landscapes of the selected districts in both cities, including signs on government offices, streets labels, toilets, warning tablets, squares, memorials, supermarkets, eateries, global companies, private business, universities and temporary fliers.

Table 2.

\section{Linguistic landscapes of the selected districts}

\begin{tabular}{|c|c|}
\hline Budapest & Bishkek \\
\hline $\begin{array}{l}\text { "Names of shops and products on the } \\
\text { windows of shops must be displayed in } \\
\text { Hungarian. Or, the above information must } \\
\text { be displayed both in a foreign language and } \\
\text { in Hungarian with the same size and with the } \\
\text { same visibility. The act applies to information } \\
\text { tables, traffic signs and warning signs as } \\
\text { well (Act XCVI on the economic and business } \\
\text { advertising signs and public announcements, } \\
2001 \text { ). }\end{array}$ & $\begin{array}{l}\text { The Law on the State language (2004) } \\
\text { requires that "the title of the country, } \\
\text { administrative and territorial units, } \\
\text { streets, squares and geographical } \\
\text { names must be written in the state } \\
\text { language, but the names of } \\
\text { enterprises, institutions and } \\
\text { organizations can be written in the } \\
\text { state and official languages", "the font } \\
\text { size of the text in other languages } \\
\text { should not exceed the font size of the } \\
\text { text in the state language" } \\
\text { (Government of the Kyrgyz Republic, } \\
\text { 2004). }\end{array}$ \\
\hline $\begin{array}{l}60 \% \text { of all visual signs are in Hungarian, } 30 \% \\
\text { bilingual with English and } 2 \% \text { bilingual with } \\
\text { Russian. The sizes of fonts and languages } \\
\text { often do not meet the requirements. }\end{array}$ & $\begin{array}{l}44 \% \text { of all visual signs in Bishkek are } \\
\text { monolingual, } 36 \% \text { bilingual with } \\
\text { Russian, } 11 \% \text { bilingual with English, } \\
8 \% \text { trilingual with English and } 2 \% \\
\text { multilingual. }\end{array}$ \\
\hline
\end{tabular}


Although, the parliament buildings do not accommodate visible inscriptions in both capitals, the important historical and symbolic monuments near the central government are monolingual. While other government buildings in Bishkek are minimum in two languages, they are in Hungarian only in Budapest. The main symbolic memorials near the parliament buildings of both countries bear monolingual inscriptions in national languages (Figure 1), but languages start topping up on the walk away from the parliaments. There is no discrepancy between the law and public signs near the parliament buildings of both countries.

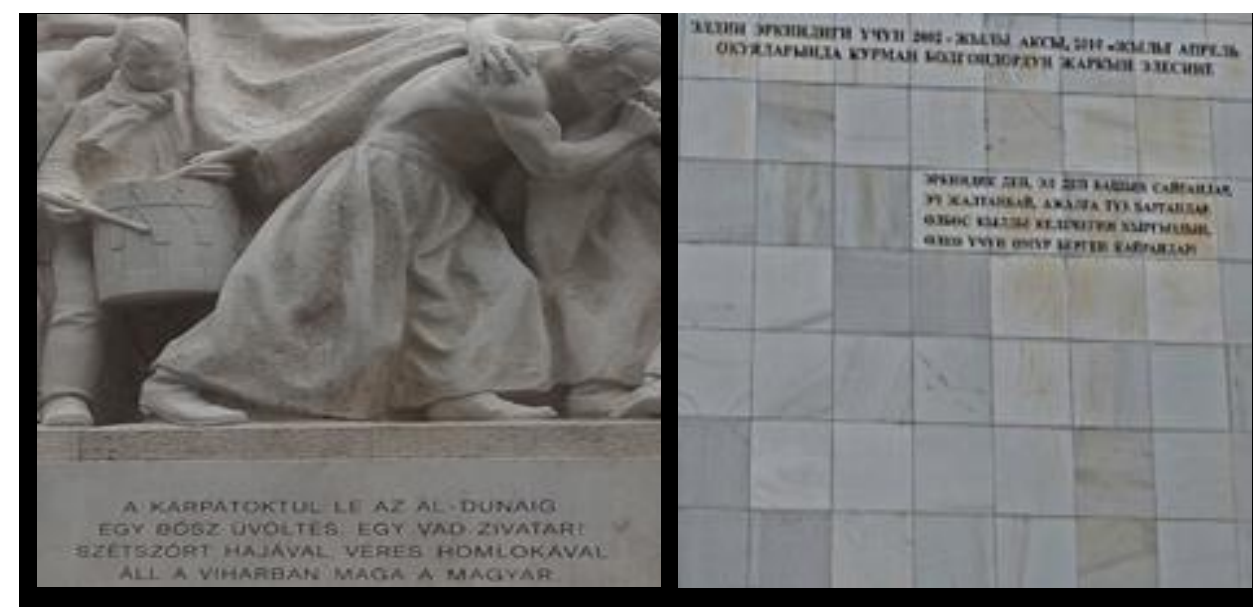

Fig. 1. Memorials with monolingual inscriptions near the parliament buildings

The cultural objects in Budapest - the Basilica, The Synagogue, the National Museum and the Liberty Square - accommodate temporary posters in several languages. The Basilica has a permanent inscription in Latin. In contrast, the central Jewish Synagogue displays three languages (English, Hungarian and Hebrew). The Liberty Square has been undergoing reconstruction since last year. The inscription on the memorial is in Russian ("Памятник Советским героям освободителям!") The same was on the posters in front of the cultural objects in Bishkek, which included the Opera Theatre, the Russian Theatre and the Kyrgyz Theatre. They are multilingual in both cities and in line with the law and the participants' attitudes. 
While most temporary signs in the central part of Budapest are in Hungarian and English, they are monolingual Russian in the center of Bishkek, where about 90 temporary commercial advertisements out of a total of 120 was in Russian. Also, a closer look of the texts in the fliers shows numerous errors indicating the difference between the languages of the authors and the advertisements. More than $90 \%$ of the temporary fliers and texts of major businesses and commercial advertisements in Bishkek on the internet are also in Russian.

The following graph (Figure 2) shows the number of public signs on government buildings, street names, public toilets, warning signals, memorials, business and commercial buildings. The signs are monolingual (mono), bilingual with English (BwE) and bilingual with Russian (BwR). As the graph demonstrates, the difference between the categories (Mono, BwE and BwR) is smaller in Bishkek (on the right) than in Budapest (on the left). The mono signs in Budapest are significantly higher than BwE on government offices (blue), street names (orange), supermarkets (yellow) and temporary advertisement (black). In contrast, the government offices and street names are in two languages in Bishkek. A similarity between the cities exists on public signs of global companies, on memorials and temporary advertisement. However, they belong to different linguistic categories.

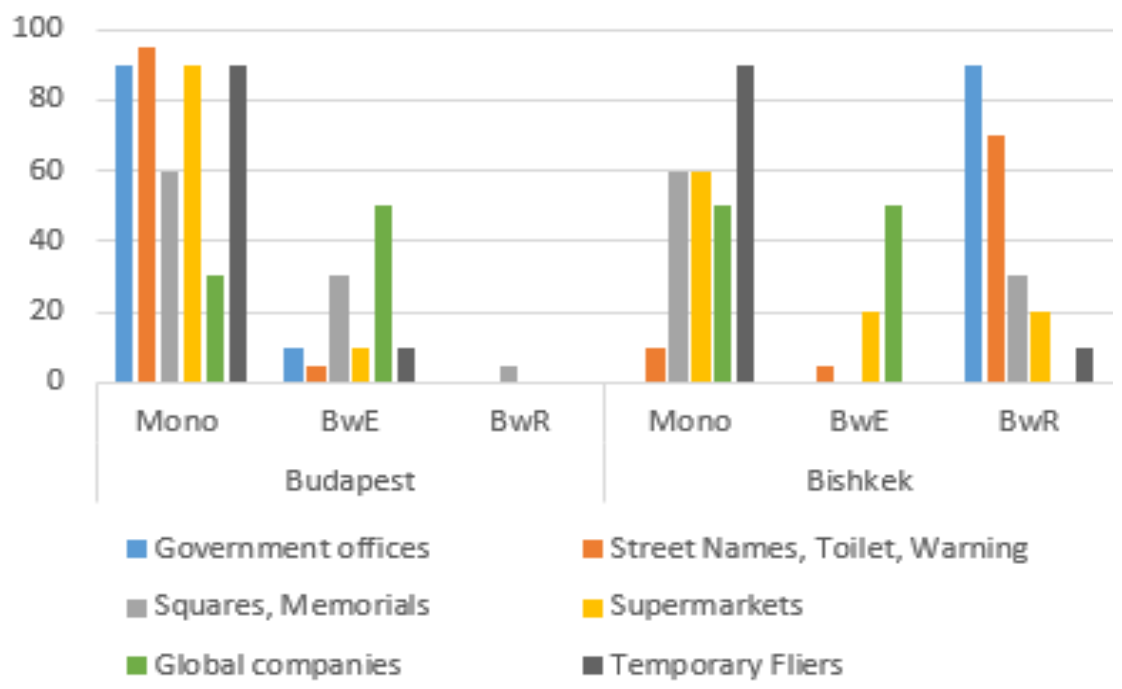

Fig. 2. Data from linguistic landscapes of the selected districts 
Although the participants in Kyrgyzstan believe in the future of Russian, they prefer only one language as the official language of their nation. In other words, there is a difference between the belief in languages and the ideologies about the number of state or official languages. Currently, Kyrgyzstan's constitution accommodates two official languages.

The fundamental law of Hungary allows only one state language, which is in line with the desire of the Hungarian participants. As the graph below (Figure 3) suggests, there is a gap, between the official LP and the participants' LI in Kyrgyzstan, which is absent in the Hungarian case.

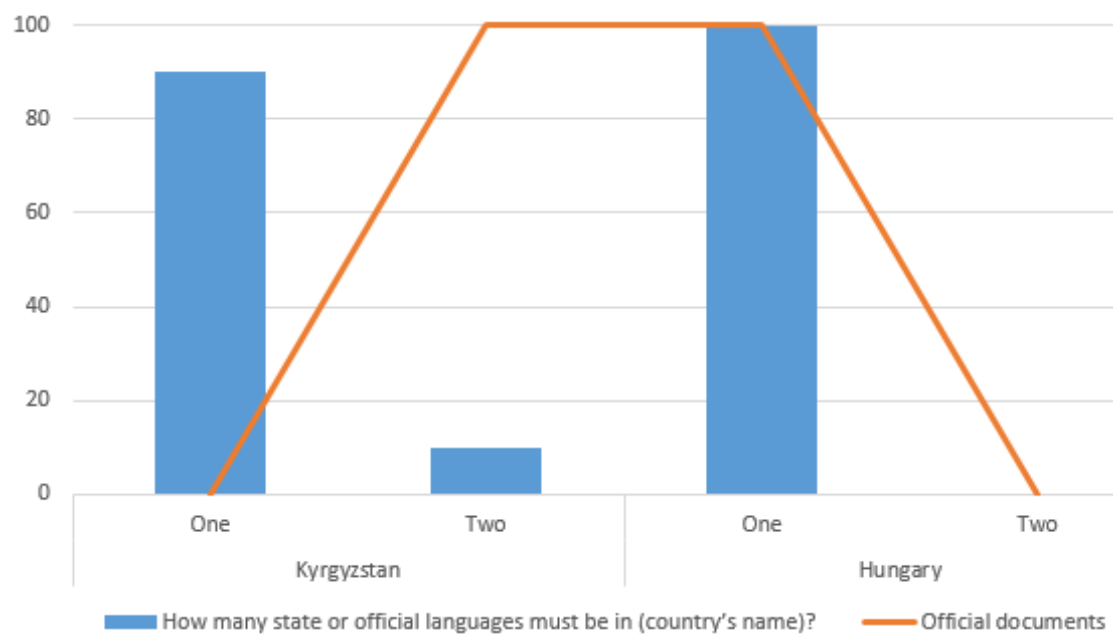

Fig. 3. The official language policy on the official or state languages and the participants' attitudes about the number of official or state languages

The data from the participants (Figure 4) coincide with the country level numbers in official records. The number of bilingual participants in Bishkek prevails the number in Budapest. While the correlation between official language policy (orange line) and the number of bilinguals is strong in Bishkek, it is much weaker in Budapest. However, this correlation does not mean that the participants support the official language policies. In other word, the two variables are not in reciprocal relationships. 


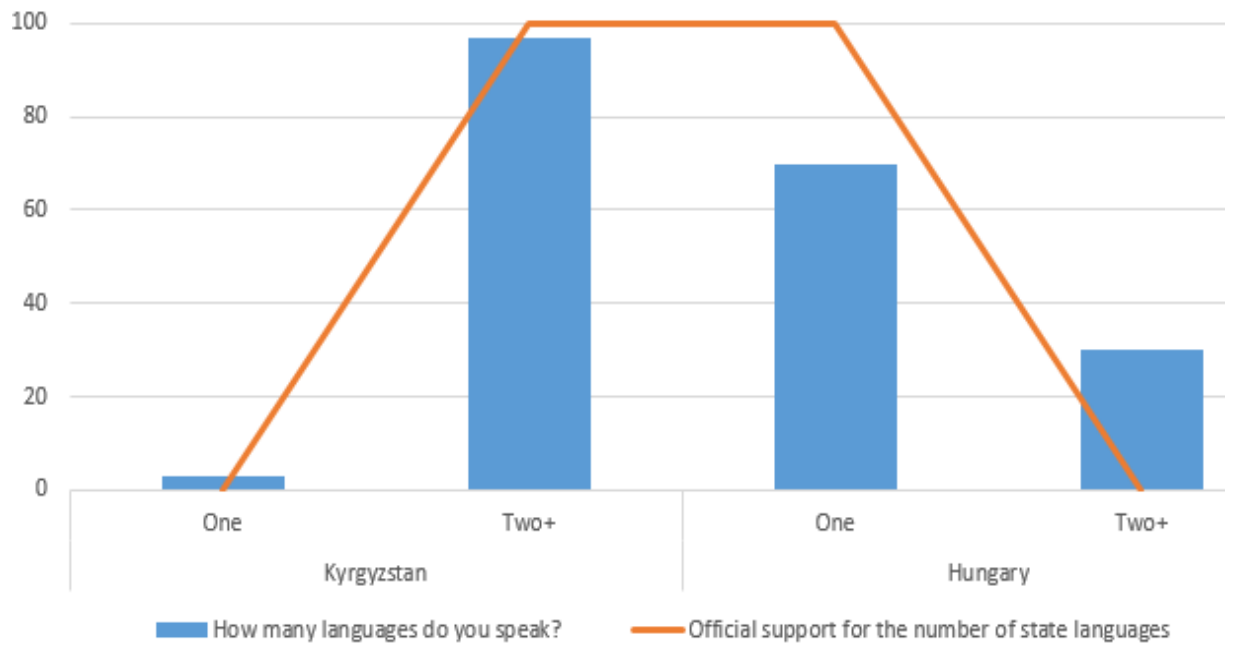

Fig. 4. Official LP and the participant's preferences towards the idea about the nation-state with one or two official languages

\section{Discussion}

This discussion shows that correlations between the data from the three sources may vary depending on contexts and that data informs about the effects of overt and covert language policies on decisions, ideologies and public signs. A retrospective analysis of historical documents in chronological order has shed light to the nuances described above. The analysis helped to understand the context of the decisions and the reactions by the national and international agencies, and the ways they contributed to discrepancies between top-down and bottom-up engagements. The comparative study also helped to understand why Hungary and Kyrgyzstan have become today representatives of monolingual and multilingual countries respectively. Their experiences contribute greatly to understand many aspects of sustainable multilingualism in similar contexts.

The findings suggest that the main direction for LP in Kyrgyzstan comes from outside and it suppresses both the government's and the people's desires. For example, the concept of development, had enforced by the Kyrgyz government, emphasized the exclusive role of the state language and the duty 
of the government to implement the state language (President of the Kyrgyz Republic, 1998). This was a serious attempt of the government to shift the position of the Kyrgyz language. The action caused the reaction of the Kremlin, which proposed another concept entitled as "The complex program of cooperation between the Government of the Kyrgyz Republic and the Government of the Russian Federation" (Government of the Kyrgyz Republic, 2001). The real intention of the "complex program" was to reverse the government's decision regarding the state language. Perhaps, a very limited number of people were aware about the importance of this incident, because it has not been mentioned anywhere even until now.

This finding validates the importance of the combination of research sources, including document analysis, LP and LL, without which explanation of the discrepancy in the results between top-down and bottom up policies would hardly be possible. It also highlights that little is known about the covert ideologies behind the struggle for the state language.

A further novel finding is that Kyrgyzstan's elite has been encouraging learning English since 1998 not only guided by economic and educational motives, but also in an attempt to release the pressure of Russian. In 2002, after the above-mentioned unsuccessful attempt, the Kyrgyz government developed the National action plan on education for all, in which "the hours for learning foreign languages have been increased" (Government of the Kyrgyz Republic, 2002). Further emphasis on English has increased since the unsuccessful attempt in 1998, as seen in the Law on Education, "In all educational institutions the study of Kyrgyz, Russian and one of foreign languages is obligatory" (Parliament of the Kyrgyz Republic, 2003). The attention to English re-emerged in 2014, when the new government issued the statement that public officials must master one of the international languages at a minimum level and all senior government officials must master one of the international languages at an advanced level (President of the Kyrgyz Republic, 2014).

Recognizing English as an official language or third language in Kyrgyzstan could strengthen Kyrgyz language by adding an alternative to the Russian versa Kyrgyz competition, and thus weakening or dispersing the dominant position of Russian. For languages in danger, implication of the third language of wider communication may serve as a balancing power to 
preserve the minor national languages (Kiyizbaeva, 2019). The experience of Kazakhstan proves that trilingualism with English has played a positive role in the development of Kazakh language.

This discussion suggests that international human rights organizations should consider the language rights not only in the national context, but also in the broader regional context. This is an important finding in the understanding of the covert issues underlying the LP processes and goes beyond previous reports, showing the hidden sources of problems in small countries such as Kyrgyzstan.

While differences between official documents and the people's desires demonstrate the gap between top-down initiatives and bottom-up ideologies, the differences between LP and LL represents the gap between official decisions and the implementation or nonfulfillment of the decisions.

Kyrgyzstan's constitution allows two national languages - Kyrgyz as the state language and Russian as the official language. However, the participants in Bishkek did not support the current LP that allows two national languages for the country. The fact that the Kyrgyz constitution equally supports two national languages, but the majority of participants wanted to see only the Kyrgyz language as both the state and official language, is a paradox (but this article will attempt to explain it later).

The unclear positions and functions of the state and official languages in Kyrgyzstan give some room for manipulations. As seen in the Figure 5, the state agency itself does not accurately follow the requirements of the law on the state language (2004), writing the title of the country in both language with the same font size. Considering the fact that the problem is on the banner of a governmental institution, the case represents a serious gap between dejure and de-facto language policies.

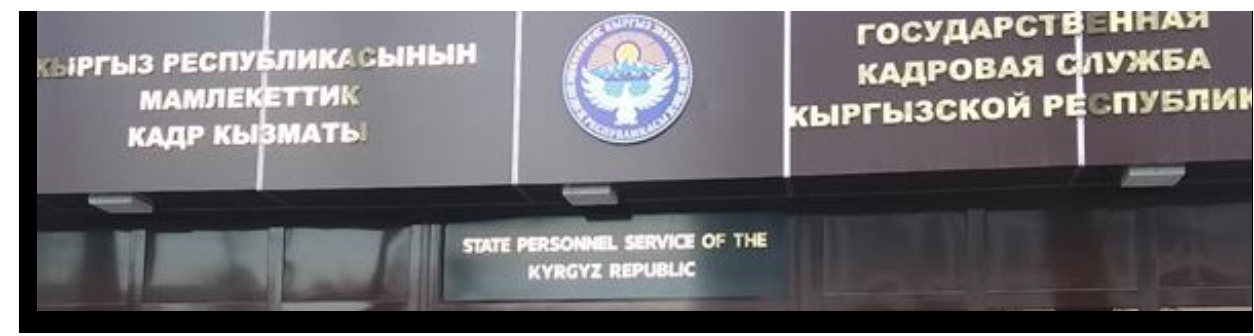




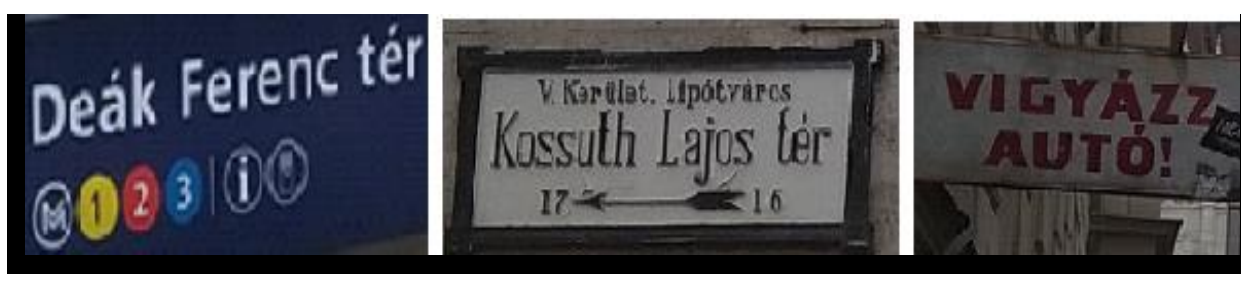

Fig. 5. Governmental/public signs in in Bishkek and Budapest

In contrast, the Hungarian fundamental law clearly states that the official language shall be Hungarian in Hungary. In addition, the Hungarian participants showed that their attitudes towards having an additional state language are negative. In the selected district of Budapest, the Act No XCVI of 2001 is observed everywhere on the governmental/public signs, including metro stations, street names and warning signs (Figure 5). Hungarian only public signs include street names, wall inscriptions about famous historical figures and events, warnings for pedestrians, parking zones, entrances to subways, etc. (Note that the situation with for profit companies is different, which will be discussed later).

These two different outcomes for the same variables make it clear that the official LP and the people's desire may or may not coincide in different contexts. The results also highlight the outcomes and reasons of the differences between top-down policies and the people's desires.

Table 1 demonstrates that both the Kyrgyz and Hungarian participants do not support two state or official languages in their countries. They also believe in two different languages of wider communication as useful for their nations' future - while the Kyrgyz believe more in Russian than in English, Hungarians do vice versa. During focus group discussions, the researcher revealed that people may believe in a language but might not like it to be the state language, because the (state) language deals with their identity. People may live with a language not liking it. People may speak in a language, even transmit it to others, but not love it. There are differences between beliefs, attitudes and ideologies regarding languages and their roles in the lives of individuals. While the Hungarians maintain the strength of their ethnic identity by speaking in Hungarian, the Kyrgyz see more value in their culture and history than speaking in Kyrgyz. A considerable number of the Kyrgyz do 
not speak in their heritage language, the fact that is absent among the Hungarians. While Russian-speaking Kyrgyz attempt to strengthen their identity by attaching to Islam, the religious Hungarians, especially the evangelical Christians, cling to Hungarian even stronger than their nonreligious compatriots do. The document analysis revealed that such incongruences point to the legacies of the past. The dominance of Hungarian language among the ethnic minorities is an outcome of language policies of the 1960s, when the government conducted inclusive LP that left no room for distrust among non-Hungarian ethnic groups, who willingly joined the main language of the country.

These findings suggest that the people's beliefs in a language and their ideologies about the language may differ, which, in turn, may have an effect on the development of language policies.

The analysis also discovered interesting parallels with Kyrgyzstan's situation in the 1930's and Hungary's situation today. It showed that the history of Hungary has not been as a line stretched between time and the national development on the Cartesian system. It was rather like a sinusoid crossing the same path of other nations many times. Following the sinusoid, what Kyrgyzstan had experienced within the SU, Hungary may cross the same points as Kyrgyzstan did, earlier or later within the EU. The trend line for modern Hungary is different than it was some hundred years ago due to the growing "Europeanness" identity. In the meantime, Hungarian participants strongly believe that English will not replace their language and they welcome English as a medium of instruction in schools, though they are aware of the growing popularity of English in Hungary. The analysis of 208 advertising spots in Hungarian television commercials concluded: "the use of English is a central linguistic expression of modernity, while the absence of English is linguistically associated with tradition" (Dorottya, 2011). However, a previous research in Hungary shows that while only 541,108 people did not answer to the question about their first language in 2001, the number of people who refused to answer the question tripled by 2011, and the proportion of those regarding themselves as Hungarians dropped from $92 \%$ to $84 \%$ by 2011 (Navracsics, 2016, p. 13). The data from the linguistic landscapes are in line with these numbers. Linguistic liberalism in the selected districts is inclined to turn into linguistic imperialism for unique languages and prone to 
wipe the state languages out of their native countries (Figure 2). International and local for profit companies, for example, preferred the languages of wider regional communication in both Budapest and Bishkek. All names of banks in the selected district of Budapest were foreign, including such titles as Unicredit bank, Iberostar Grand Budapest, Ciao Mamma Hungarian Italian Restaurant, Bagel Donut, Selection BBQ, Burger and Beer, Istanbul Kebab, Breakfast, Lunch, Dinner, Mangalica, Souvenir Shop, Currency Exchange, City Center, Thai Massage, Sightseeing, Concert Ticket Sale, The Donut Library, etc. The two images below demonstrate the gap in both cities. The case in the Figure 6 ignores the law of Hungary by not providing translation into the official language of Hungary. Some languages tend to replace the national languages of hosting countries completely as is seen in the same figure. It is not clear, however, whether logos should count for texts of advertisements, or not.

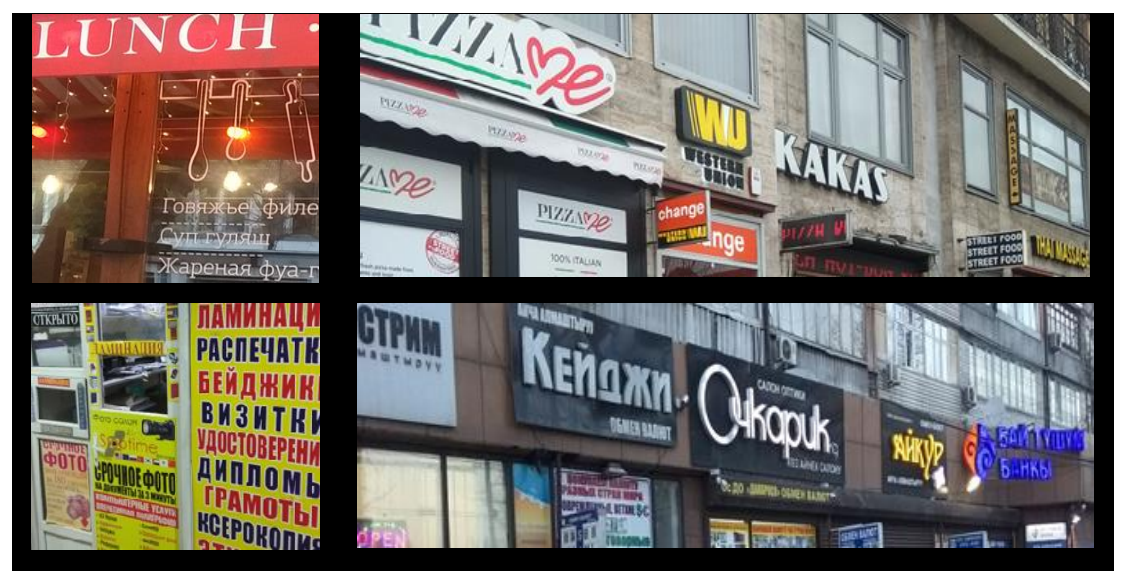

Fig. 6. International and local for profit companies in Budapest (above) and Bishkek (below)

These results go beyond previous reports, showing that the linguistic imperialism takes place not only due to profit, but also because of ambiguities in the legislature. Furthermore, the current multilingual language policy in the EU has a potential to produce similar outcomes for Hungary as the multilingual SU policy did for Kyrgyzstan. This finding also has a potential for further policy implication, since it suggests/warns that covert external LP factors may have long lasting effects when they are different from official 
policies and the people's beliefs. The finding also confirms our hypothesis that the combination of research methods and sources provides better results than when they are stand-alone.

Official documents in Kyrgyzstan encourage teaching and learning all three languages - Kyrgyz, Russian and English. The strongest support is provided for Kyrgyz, then for Russian, and then for English. Hungary's official documents provide strongest support for Hungarian, then to other languages. The trend line of official support follows the attitudes of the participants in both countries (Figure 4). (Note that there is a difference between the people's desire to learn other languages and their ideologies about the number of state languages.) As is seen in the Figure 4, the overwhelming majority of Kyrgyzstani participants are bilingual, which corresponds to the linguistic landscape of the selected district. In Hungary, the ratio is reverse and corresponds to the LL of the selected district in Budapest. This result suggests that LL reflects (strongly correlates with) the language ecology of the population. It also demonstrates that when top-down and bottom-up ideologies coincide, the country is able to develop "a common language", which in turn positively correlates with the LL. In other words, there is a strong correlation between official support to particular languages and the people's attitudes towards these languages (Figure 4).

\section{Strength and Limitations of the Study}

The strength of the study comes from the three methods and three sources of data in combination with comparative approach. These sources complement each other, minimize incongruences that might arrive from using a single source and ensure the accuracy of conclusions. Another strength is that the researcher lives in both countries and has a firsthand access to the sources. The limitations include the small size of participants, scarcity of recent data and the researcher's limited fluency in Hungarian language. 


\section{Conclusions}

The study showed that both overt and covert language policies, as well as historical decisions have played the major role in forming current sustainable multilingualism and monolingualism in Kyrgyzstan and Hungary respectively. It also revealed that the current trend to study language policies using one single method is not sufficient to understand accurately the language policies of political entities.

\section{Acknowledgments}

The researcher is grateful to professors at the Kyrgyz National University, Kyrgyz State University and Bishkek Humanitarian University, including Dr. Ishekeev, Dr. Sadyk Sher, Prof. Segizbaeva, Prof. Kadirbekova, Prof. Baisabaev, Prof. Jumagazieva, Prof. Kakishev and Prof. Ermatova. His appreciation goes to proofreaders of this article: Richard Hewitt and Daniel Vail (USA). He wants to acknowledge his consultants at the School of Multilingualism of the University of Pannonia Dr. Navracsics and Dr. Csernicsko. He also wants thank Soros foundation in Kyrgyzstan for supporting this project and Vytautas Magnus University in Lithuania for organizing this important conference.

\section{References}

Ajsic, A., \& McGroarty, M. (2015). Mapping Language Ideologies. In F. Hult, \& D. Johnson (Eds.). Wiley Blackwell.

Batyi, S. (2015). The place-making activity of Russian in Hungary. In K. Kovačević, \& S. Udier (Ed.), Multidisciplinary Approaches to Multilingualism: Proceedigs from the CALS conference (pp. 115-130). Frankfurt am Main: Peter Lang Verlag: Researchgate.

Bayley, R., \& Villarreal, D. (2018). Cultural Attitudes Toward Language Variation and Dialects. Willey Online Library. doi: 10.1002/9781118784235. eelt0297. 
Blackledge, A. (2008). Language Ecology and Language Ideology. (N. Hornberger, Ed.) Boston: Springer. doi: 10.1007/978-0-38730424-3.

Chotaeva, C. (2003). Language Policy and Language Situation in Kyrgyzstan. Tohoku: iddle Eastern And Central Asian Studies Group, Tohoku University, 2003.

Dorottya, P. (2011). English in Hungarian advertising. World Englishes, 21-40. doi: $10.1111 / \mathrm{j} .1467-971 X .2010 .01685 . x$

Gorter, D., \& Cenoz, J. (2012). Regional minorities, education and language revitalization. In Handbook of Multilingualism (pp. 194-198). Routledge.

Gorter, D., \& Cenoz, J. (2017). Encyclopedia of Language and Education: Linguistic Landscape and Multilingualism. In J. Cenoz, D. Gorter, \& S. May (Eds.), Language Awareness and Multilingualism (Third ed., pp. 233-245). Cham, Switzerland: Springer International Publishing. doi: 10.1007/978-3-319-02240-6.

Government of the Kyrgyz Republic. (2001). Complex program of cooperation between the Government of the Kyrgyz Republic and the Government of the Russian Federation to meet the national and cultural needs of the Russian population of the Kyrgyz Republic (including Russian) and the Kyrgyz populatio. Retrieved from http://cbd.minjust.gov.kg/act/view/ru-ru/15655.

Government of the Kyrgyz Republic. (2002). National action plan on education for all. Retrieved from http://cbd.minjust.gov.kg/act/view/ruru/53774?ckwds=\%25d1\%258f\%25d0\%25b7\%25d1\%258b\%25d0\% 25ba.

Hungarian Education Office. (2011). Legal Texts is a Hungarian Education and Recognition Matters. Retrieved from https://www.oktatas.hu/pub_bin/dload/nyelvvizsga_honositas/elisme rtetes_honositas/english/act_national_education.doc.

Hungarian government. (2011). The Fundamental Law of Hungary. Retrieved from https://hunconcourt.hu/uploads/sites/3/2018/11/ thefundamentallawofhungary_20181015_fin.pdf.

Kashybaeva, A. (2014). Why we do not want our children learn in Kyrgyz? Weekly Newspaper under the Ministry of Education and Science of 
the Kyrgyz Republic (Kutbilim). Retrieved from http://kutbilim.kg/kg/2014/02/25/baldaryibyizdyi-kyirgyizchaokutuudan-nege-kyiyyilabyiz-2/.

Liu, R. (2012). Language Policy and Group Identification in Taiwan. Mind, Brain, and Education, 6(2), 108-116.

Mambetaliev, A. (2018). A History of Pluralism in Kyrgyzstan. Ottawa: Global Centre of Pluralism. Retrieved from https://www.pluralism.ca/wpcontent/uploads/2018/04/Askar-Mambetaliev-English-Apr2018-

FINAL.pdf.

Kiyizbaeva, C. (2019). European education system is showing a good trend forward. Weekly Newspaper of the Ministry of Education and Science of the Kyrgyz Republic. Retrieved from http://kutbilim.kg/kg/2019/01/31/askar-mambetaliev-vengriyanynpanoniya-universitetinin-doktoranty-evropanyn-bilim-ber-sistemasyalda-kancha-aldyga-ketiptir.

Mavlianova, M. (2019). Language policy is being weak. Radio Liberty/Radio Free Europe. Retrieved from https://www.youtube.com/watch?v=ycvE4LoahgQ.

Moore, S., \& Wiley, T. (2015). Interpretive Policy Analysis for Language Policy. In F. Hult, \& C. Johnson (Eds.), Research Methods in Language Policy and Planning. Willey Blackwell.

Navracsics, J. (2016). Living with two languages and cultures. The complexity of self-definition for bilingual individuals. Hungarian Journal of Applied Linguistics, XVI. doi: 10.18460/ANY.2016.2.006.

Ornstein, J. (1959). Soviet Language Policy: Theory and Practice. The Slavic and East European Journal, 3(1), 1-24. Retrieved from https://www.jstor.org/stable/305536.

Parliament of the Kyrgyz Republic. Law on Education of the Kyrgyz Republic. Retrieved from http://cbd.minjust.gov.kg/act/view/ru-ru/1216.

Pasquale, M., \& Bierma, N. (2011). Every Tribe and Tongue: A Bilical Vision for Language in Society. Oregon: Wipf and Stock Publishers.

Paulik, A., \& Solymosi, J. (2004). Language policy in Hungary. Retrieved from http://www.gencat.cat/llengua/noves/noves/hm04primaveraestiu/docs/paulik.pdf. 
President of the Kyrgyz Republic. (1998). Concept of development of the state language of the Kyrgyz Republic. Retrieved from http://cbd.minjust.gov.kg/act/view/ru-ru/2563?ckwds=\%25d1\% $258 f \% 25 d 0 \% 25 b 7 \% 25 d 1 \% 258 b \% 25 d 0 \% 25 b a$.

President of the Kyrgyz Republic. (2014). The National Program for the development of the state language and the improvement of language policy in the Kyrgyz Republic for 2014-2020. Retrieved from http://cbd.minjust.gov.kg/act/view/ru-ru/63683?ckwds=\%25d1\% $258 f \% 25 d 0 \% 25 b 7 \% 25 d 1 \% 258 b \% 25 d 0 \% 25 b a$.

Raza, M. (2015). Language Attitude and English Language Learning in Pakistan. Communication studies and language pedagogy. Retrieved from https://www.researchgate.net/publication/322445848_ Language_Attitude_and_English_Language_Learning_in_Pakistan.

Rukh, S. (2014). Students' Attitude towards English Language Learning and Academic Achievement: A Case of Business Students in Punjab. European Academic Research, 2(4). Retrieved from https://www.academia.edu/7568752/Students_Attitude_towards_Eng lish_Language_Learning_and_Academic_Achievement_A_Case_of_Bu siness_Students_in_Punjab.

Second All Kirghiz Conference of the Kyrgyz ASSR, (1929). The Constitution of the Kyrgyz ASSR.

Shohamy, E. (2015). LL research as expanding language and language policy. Linguistic Landscape, 1(1/2), 152-171. doi: 10.1075/II.1.1/2.09sho.

Smagulova, J. (2008). Language Policies of Kazakhization and Their Influence on Language Attitudes. The International Journal of Bilingual Education and Bilingualism, 11(3/4), 440-475. doi: $10.1080 / 13670050802148798$.

Spolsky, B. (2004). Language Policy: Key Topics in Sociolinguistics. Cambridge: Cambridge University Press.

Supreme Council of the Kyrgyz Republic, (1993). The Constitution of $\begin{array}{llll}\text { the Kyrgyz } & \text { Republic. } & \text { Retrieved }\end{array}$ http://cbd.minjust.gov.kg/act/view/ru-ru/1. 


\section{Askar Mambetaliev}

Panonijos universitetas, Vengrija

amambetaliev@alumni.umass.edu

\section{ATOTRŪKIO TARP DE JURE IR DE FACTO KALBU POLITIKOS LYGINAMASIS TYRIMAS: KIRGIZIJOS IR VENGRIJOS ATVEJIS}

Santrauka. Šio tyrimo tikslas - nustatyti pagrindinius faktorius, kurie nulemia kalbu politika, ir atrasti koreliacijas tarp ideologiju "iš viršaus i apačią" bei "iš apačios i viršu" Vengrijos ir Kirgizijos kontekste. Igyvendinant ši tiksla, buvo sukurta duomenu bazè, kuria sudarè aktualūs oficialūs dokumentai, kalbiniu kraštovaizdžiu nuotraukos ir kokybiniai duomenys. Tyrimo metu dokumentais patvirtinti sprendimai "iš viršaus i apačia" buvo išanalizuoti istoriniu požiūriu bei palyginti su duomenimis, surinktais iš interviu, apklausu ir nuotrauku rinkinio. Tarp dalyviu buvo aukšto rango politiku, profesoriu, studentu ir atsitiktiniu piliečiu. Rezultatai parodè, jog oficialios politikos kryptys dažnai visapusiškai neatitinka žmoniu isitikinimu, pažiūru bei troškimu. Atradimai taip pat leidžia manyti, kad vien dokumentu analizès, kalbinio kraštovaizdžio metodo arba kokybiniu metodu naudojimo gali nepakakti rezultatu pagrindimui, jei likusieji metodai nèra naudojami, kadangi gali atsirasti klaidu, kylančiu dèl ivairiu neatitikimu tarp „iš viršaus i apačia” ir "iš apačios i viršu” metodu bei dèl atviru ir užslèptu ideologiju.

Pagrindinès sąvokos: kalbu politikos; ideologijos; isitikinimai; dokumentu analizè; kalbinis kraštovaizdis. 